\title{
On the Energy Exchange between the Atmosphere and the Sea East of Japan*
}

\author{
Keinosuke MoтоHASHI ${ }^{* *}$ and Michitaka UdA ${ }^{* *}$
}

\begin{abstract}
The energy exchange between the atmosphere and the sea at the the selected six stations east of Japan has been studied for the period 1960-1962, within the limited months (September-April). The monthly variations of total energy exchange and sea surface temperature throughout the three years 1960-1962 indicated the increase or decrease of sea surface temperature following about two months after the decrease or increase of total energy exchange. The amount of total energy exchange $\left(Q_{a}\right)$ and the difference of atmospheric "core pressure" between the Siberian High and the Aleutian Low $(\Delta p)$ are closely correlated in the following: $Q_{a}=[f(\varphi) g(t)] \Delta p$, where the proportional coefficient depending on latitude $(\varphi)$ and month $(t)$ is denoted as $f(\varphi) \cdot g(t)$ and practically $f(\varphi)$ is replaced by $(-a \varphi+a)$. This equation suggests that the total energy exchange over the sea east of Japan can be predicted quantitatively from the atmospheric pressure distribution. Basing on the heat budget, the estimated cooling due to the advection of Oyashio current in colder season is most remarkable during December, and the sea east of Japan is subdivided into two characteristic areas by about Lat. $37^{\circ} 30^{\prime} \mathrm{N}$, namely, the southern area influenced more by the Kuroshio and the northern area influenced more by the Oyashio.
\end{abstract}

\section{Introduction}

The heat budget between the atmosphere and the sea is becoming essentially important for many theoretical and applied problems in oceanography and meteorology as emphasized by several groups of researchers.

Meanwhile recently several works on such heat budget appeared following the classical contributions by SVERDRUP (1937, 1940), JACOBS (1941-1951), and BuDYKo (1956). The great majority of them has dealt with the global heat flux and climatological heat exchange. Concerning the heat budget on the waters adjacent to Japan we may refer to the following contributions such as HANZAWA (1950), MASUZAWA (1951), MiYAZAKI (1952), KoIZUMI (1956), MANABE (1958), OTSUKA (1964), and in the Pacific and Atlantic Oceans LaEvastu (1963), NAmias (1963), Malkus (1962), BJERKNES (1964) and WYRTKI (1965, 1966).

* Received July 31, 1967

** Tokyo University of Fisheries
In the present paper we have obtained the relation between the monthly total energy exchange and the monthly variations of sea surface temperature, and studied to be able to predict the total energy exchange quantitatively as well as to estimate the amount of heat added to or removed from through advective processes over the sea east of Japan. Investigation was made on the monthly averaged data for the period 1960-1962, excluding the radiation terms of heat budget.

\section{Data and its processing}

We assumed to utilize the observed values at the 10 meters height for the latter elements among the following six elements necessary to compute the components of heat budget, namely sea surface temperature, cloud cover, wind speed, atmospheric pressure, atmospheric vapor pressure and air temperature, and adopted the combined data existing in Japan from "Maritime Meteorological Table in the North Pacific Ocean" published by the Japan Meteorological Agency.

The sea surface temperature data was read 
from "Ten-day Marine Report" published by the Japan Meteorological Agency, and from the M.S. Reports by the Pacific Oceanographic Group (Fisheries Research Board of Canada). Air temperature $\left(t_{a}\right)$ and vapor pressure $\left(e_{a}\right)$ data were checked by Miyazaki's method (1952) showing the linear relation $e_{a}=f\left(t_{a}\right)$. Observed wind speed data was used as recommended by LAEVASTU(1963), who remarked a considerable deviation of actually reported wind from the geostrophic one occasionally. However, the available computed wind speed is two-third of the geostrophic one as PETTERsSEN (1956) pointed out.

Mean monthly values of those elements were computed for each grid of one-degree Lat. and two-degree Long., within the limited area, from Lat. $35^{\circ} \mathrm{N}$ to $40^{\circ} \mathrm{N}$, and from the east coast of Japan to Long. $155^{\circ} \mathrm{E}$.

\section{The equation for the heat balance}

The equation for the heat balance in any part of the ocean in a given time interval can be, in general, represented as follows:

$$
Q_{s k}-Q_{b}-Q_{s}-Q_{e}-Q_{\theta}+Q_{v}=0,
$$

where

$Q_{s k}$ : Total incoming radiation from solar and sky (short-wave) radiation

$Q_{b}$ : Effective back radiation from the sea surface (long-wave radiation)

$Q_{s}$ : Convection of sensible heat to the atmosphere

$Q_{e}:$ Amount of heat used for evaporation

$Q_{\theta}$ : Amount of heat used locally for raising the temperature of sea water

$Q_{v}$ : Amount of heat added to through advection

By putting $Q_{s k b}=Q_{s k}-Q_{b}$ and $Q_{a}=Q_{s}+Q_{e}\left(Q_{a}\right.$; Air-sea exchange, the so-called "Total Energy Exchange"), the equation can be reduced to

$$
Q_{v}=Q_{a}+Q_{\theta}-Q_{s k b}
$$

where $Q_{s k}$ depends on the latitude, month, cloud cover, and on the turbidity of air, $Q_{b}$ on the cloud cover and sea surface temperature, but they have not been treated in this paper. The components of the above equation will be discussed later in some details.

\section{Formulae for computation of $\boldsymbol{Q}_{e}$ and $\boldsymbol{Q}_{\boldsymbol{s}}$}

The amount of heat used for evaporation $Q_{e}$ and the exchange of sensible heat by convection $Q_{s}$ may be deduced indirectly by two methods, one using "Budget formulae" on the concept of "Bowen ratio", the other based on the laws of small-scale molecular and turbulent transfer which give the exchange as a function of the air-sea property differences and wind speed, the so-called "Exchange formulae". The former is, in general, suitable for the broader regions and longer periods, and the latter suitable for the smaller scale areas and shorter periods.

In this paper, $Q_{e}$ and $Q_{s}$ have been computed according to the equations similar in form used by MALKUS (1962) and WYRTKI (1963), that is, by the latter method:

$$
\begin{aligned}
& Q_{e}=\rho_{a} \cdot C_{d} \cdot L\left(e_{w}-e_{a}\right) \cdot W_{a} \\
& Q_{s}=\rho_{a} \cdot C_{d} \cdot C_{p}\left(T_{w}-T_{a}\right) \cdot W_{a},
\end{aligned}
$$

where

$\rho_{a}$ : Density of the air, assuming that the value is $1.2 \times 10^{-3} \mathrm{~g} / \mathrm{cm}^{3}$

$L:$ Latent heat of evaporation

$\boldsymbol{e}_{w}$ : Saturation specific humidty at the sea surface temperature

$e_{a}$ : Actual atmospheric specific humidity at $a \mathrm{~m}$ level from sea surface

$C_{p}$ : Specific heat of the air at constant pressure, assumed the value $0.24 \mathrm{cal}$. $\mathrm{g}^{-1} \mathrm{deg}^{-1}$

$T_{w}$ : Sea surface temperature

$T_{a}$ : Air temperature at $a \mathrm{~m}$ level from sea surface

$C_{d}$ : Drag coefficient, which depends on the wind speed $W_{a}$, height of observation and character of stratification

$T_{a}, e_{a}$, and $W_{a}$ are observed at 10 meters height, and MALKUS and WYRTKI used the value $C_{d}=1.4 \times 10^{-3}$ and $C_{d}=1.55 \times 10^{-3}$ at the average wind speed of $7.2 \mathrm{~m} / \mathrm{sec}$ and $8 \mathrm{~m} / \mathrm{sec}$, respectively.

In the area treated in the present paper, however, the wind speed varies in a day or in a month accompanying to the development and 


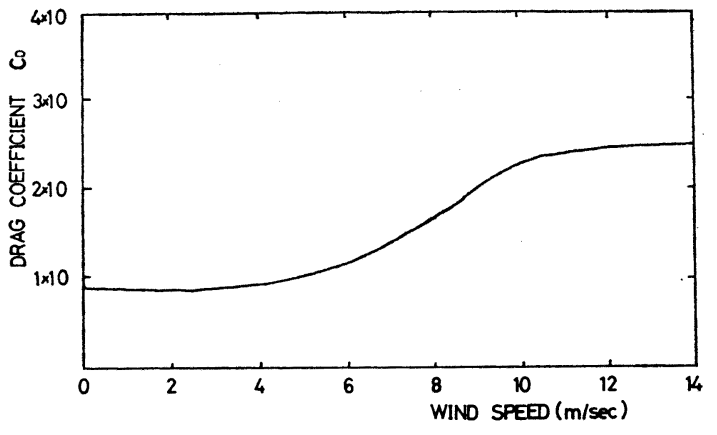

Fig. 1. Relationship between the drag coefficient and the wind speed. (After DEACON, SHEPPARD and WEBB, 1956, Fig. 5)

decay of the Siberian High, Aleutian Low, and North Pacific High. This drag coefficient has been, therefore, read from the Figure 1, illustrating the relation between drag coefficient and wind speed at 10 meters height (DEACON, SHEPPARD and WEBB, 1956).

\section{Formula for computation of $Q_{\theta}$}

The amount of heat used locally for changing the temperature of sea water is computed according to the following equation

$$
Q_{\theta}=\rho \cdot C_{p} \int_{0}^{\infty} \frac{\partial \theta}{\partial t} d z,
$$

where $\rho$ is the density of sea water, $C_{p}$ specific heat of sea water at constant pressure, $\theta$ sea water temperature, $t$ time, and $z$ depth. The upper limit of the integration may be, in practice, substituted by the depth of thermocline.

In such case, however, the basic assumptions underlying the substitution of thermocline depth are that the upper water depth down to the thermocline is well mixed enough to neglect the vertical gradient of temperature, and that exchange of heat through the thermocline is negligible, and also that the temperature difference due to the monthly variation of thermocline depth is negligible. It is assumed, furthermore, that on the average $\rho \cdot C_{p}$ is 1.024 , whereas in general $\rho \cdot C_{p}$ varies with sea water temperature and salinity.

The monthly averaged thermocline depth $Z$ is indicated in Table 1, taken from "The Results of Marine Meteorological and Oceanographical Observations" published by the Japan Meteorological Agency.

\section{Monthly variations of the total energy ex- change and the sea surface temperature}

Figure 2 illustrates the monthly variations of total energy exchange $\Delta Q_{a}$ and sea surface temperature $\Delta t$ at the selected six stations (Fig. 3). The positive sign means the increase of sea surface temperature higher than previous month, and the decrease of total energy exchange, and the negative sign means vice versa.

Although the distributions patterns of $\Delta Q_{a}$ and $\Delta t$ respectively run parallel to the latitude, their quantities vary with the latitude. The $\Delta Q_{a}$ decreases toward the higher latitudes and varies with season.

The change of sea surface temperature, $\Delta t$ in the southern area bounded by the Lat. $37^{\circ} 30^{\prime} \mathrm{N}$ (as defined in the last chapter in this paper, corresponding to the Oyashio Front or Polar Front i.e. Subarctic Covergence) is not conspicuous with latitude and season, but in the northern area $\Delta t$ varied in considerable degree. This fact shows that in the southern area bounded by the Lat. $37^{\circ} 30^{\prime} \mathrm{N}$ the sea surface temperature is maintained mainly by the advection from the Kuroshio current. The sea surface temperature in the northern area, on the other hand, is greatly affected by the influence of local processes rather than advection in the warmer season.

In order to demonstrate the above, the difference between mean monthly sea surface temperature and air temperature at the 10

Table 1. Monthly averaged thermocline depth $(Z)$.

\begin{tabular}{rrrrrrrrr}
\hline Month & Sept. & Oct. & Nov. & Dec. & Jan. & Feb. & Mar. & Apr. \\
$Z(m)$ & 50 & 75 & 100 & 150 & 200 & 200 & 150 & 100 \\
\hline
\end{tabular}



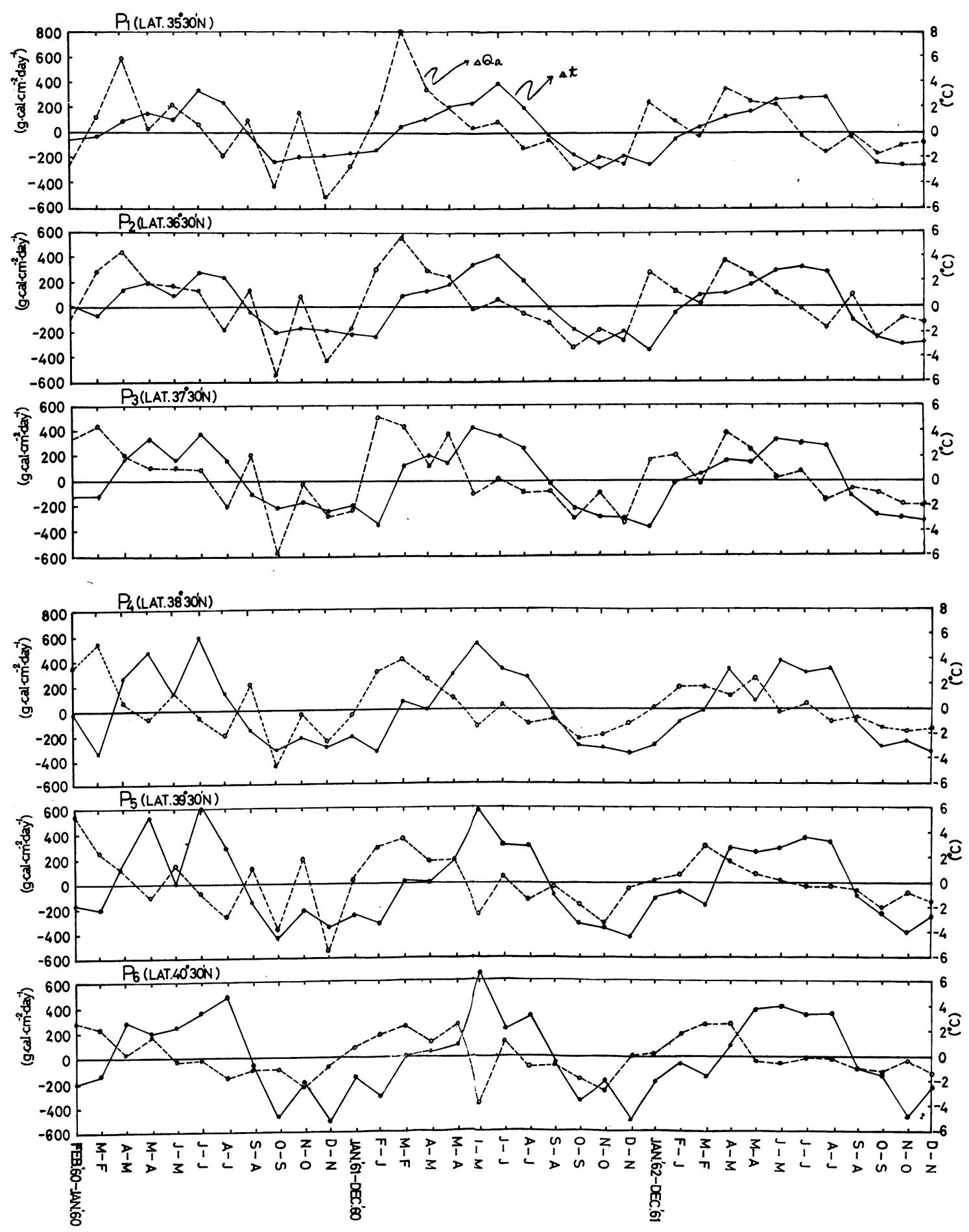

Fig. 2. Monthly variations of total energy exchange $\Delta Q_{a}$ (dotted line) and sea surface temperature $\Delta t$ (solid line) at the selected six stations in the sea east to Japan as shown in Fig. 3. 


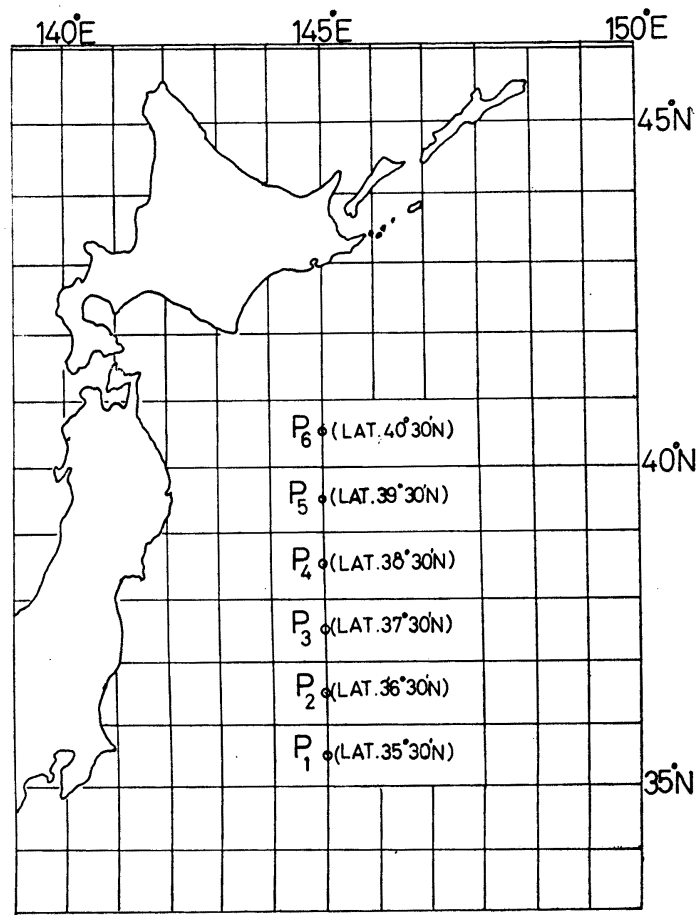

meters height $\left(t_{w}-t_{a}\right)$ and the difference between saturated vapor pressure and actual atmospheric vapor pressure $\left(e_{w}-e_{a}\right)$ are shown in Figure 4.

Along the Lat. $37^{\circ} 30^{\prime} \mathrm{N}$, the sea surface temperature is higher than air temperature during the years as a whole, and along the Lat. $40^{\circ} 30^{\prime} \mathrm{N}$, on the other hand, it is rather lower than the air temperature during months more than half of years.

The effect on the variations of sea surface temperature in the northern area is, therefore, due to the influence of local external processes, that is mainly due to the effect of air temperature. Considering the variation of an amount of energy exchange in course of years, the difference between saturated vapor pressure and actual vapor pressure is larger in the southern

Fig. 3. Selected six stations adopted along the Longitude of $145^{\circ} \mathrm{E}$ from the Latitude $40^{\circ} 30^{\prime} \mathrm{N}$ to the Latitude $35^{\circ} 30^{\prime} \mathrm{E}$.
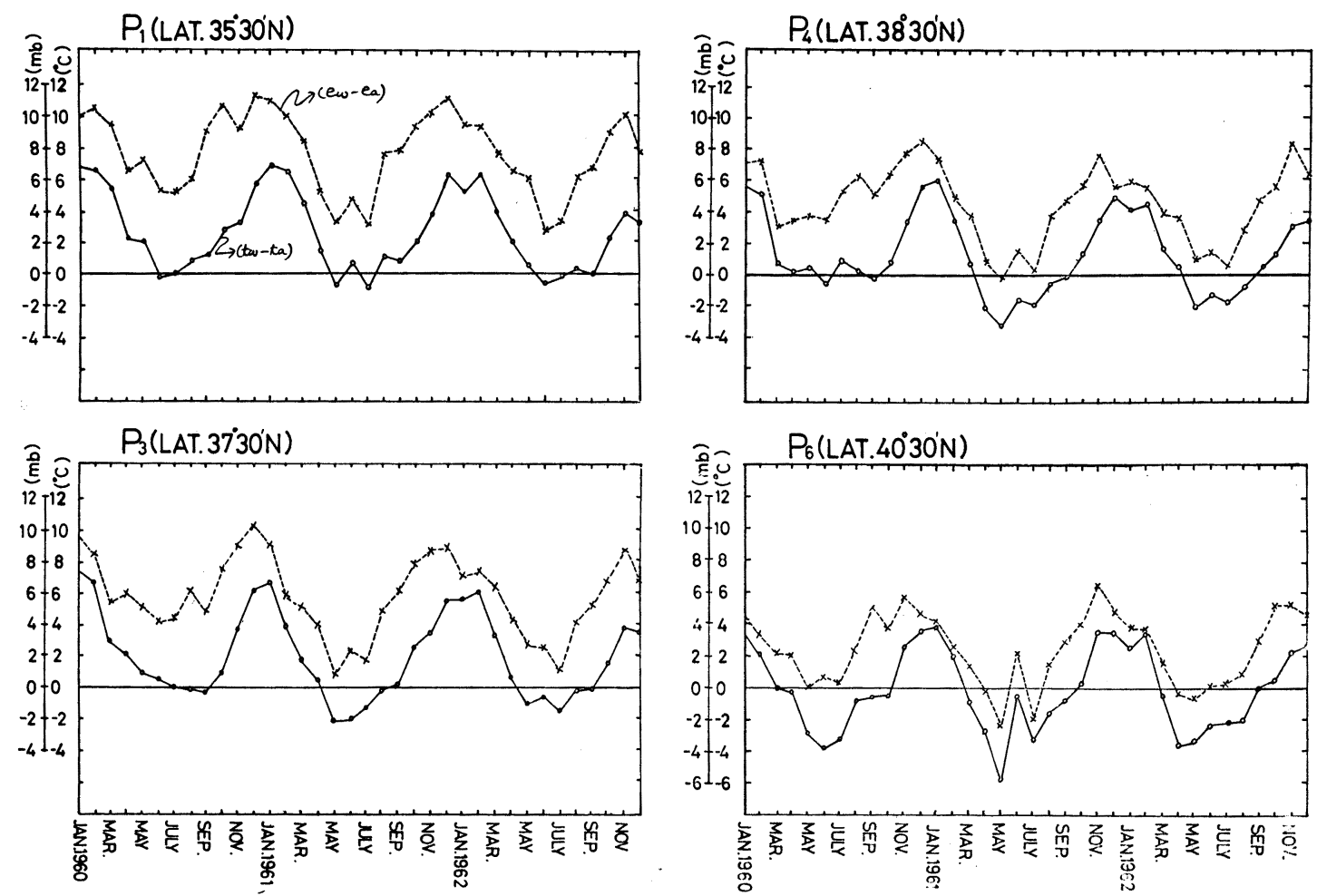

Fig. 4. The difference between mean monthly sea surface temperature and air-temperature in ${ }^{\circ} \mathrm{C}\left(t_{w}-t_{a}\right)$ (in solid line), and the difference between saturated vapor pressure and actual atmospheric vapor pressure in $m b\left(e_{w}-e_{a}\right)$ (in dotted line). 
area, and less in the northern area. This indicates that the amount of energy exchange decreases toward the higher latitude. In particular, the months in which actual vapor pressure exceeds saturated vapor pressure are expected to correspond to the period of sea-fog development.

Lastly, two periods concerning the sea surface temperature are distinguished somewhat definitely i.e. a period of temperature rise from March to September, another period of temperature fall from September to March, and also concerning the amount of energy exchange two periods are distinguished roughly, a period of decrease from January-February to JulyAugust, another period of increase from JulyAugust to January-February. From this point of view, we can expect that the increase of sea surface temperature begins two months after the decrease of energy exchange, and the decrease about two months after the increase of energy exchange.

\section{Relation between total energy exchange and the atmospheric "core pressure" difference of the Siberian High and the Aleutian Low}

The prevailing wind over the sea east of Japan depends on the pressure gradient and location of the Siberian High and the Aleutian Low in the colder season, both of which appear in September and vanish in April, in general. Therefore, the atmospheric "core pressure" difference between the Siberian High and the Aleutian Low has been represented as an indicator of prevailing wind over the abovementioned area.

Since $Q_{e}$ and $Q_{s}$ are in proportional to wind speed according to the equations (3) and (4), the relation between total energy exchange $Q_{a}$ and the above-mentioned atmospheric "core pressure" difference $\Delta p$ will be discussed below.

At present, the atmosheric "core pressure" differences were taken from "The Monthly Mean Pressure Chart in the Northern Hemisphere" by the Japan Meteorological Agency, as shown in Table 2.

The mean monthly variation of total energy exchange for the period of 1960-1962, relating to the atmospheric " core pressure" difference, are shown in Fig. 5. The more the atmospheric "core pressure" difference increases, the more total energy exchange increases, and vice versa. Also the energy exchange is varied with latitude and month. In order to investigate this fact, Fig. 6 is prepared to illustrate the distribution of $Q_{e}$ and $Q_{s}$. Before discussing those, we have to be in mind that wind speed is related mainly $Q_{e}$ and air-sea temperature difference related to $Q_{s}$. The corresponding effects of air-sea temperature difference on $Q_{e}$ and wind speed on $Q_{s}$ are secondary, respectively.

In September, October, November, and April, $Q_{s}$ is not varied much with latitude, but $Q_{e}$ decreases toward the higher latitudes.

In December, January, February, and March, both of $Q_{e}$ and $Q_{s}$ have a tendency of decrease toward the higher latitudes, especially that of $Q_{e}$ is a considerable one. During these months, the severe northwest monsoon of poor atmospheric vapor content and very low air temperature is prevalent and the effect of sensible heat depending on air-sea temperature difference plays an important rôle for the total energy

Table 2. Atmospheric "core pressure" difference between the Siberian High and the Aleutian Low.

\begin{tabular}{c|rrrrrrrr}
\hline Month & Sept. & Oct. & Nov. & Dec. & Jan. & Feb. & Mar. & Apr. \\
\hline 1960 & 12.5 & 30.6 & 32.6 & 48.2 & 46.5 & 38.0 & 20.1 & 18.6 \\
1961 & 13.9 & 24.5 & 31.6 & 36.2 & 54.4 & 36.6 & 29.9 & 6.0 \\
1962 & 15.5 & 27.5 & 44.3 & 33.7 & 43.2 & 41.6 & 28.9 & 18.6 \\
Mean & 13.9 & 27.5 & 36.9 & 40.0 & 48.0 & 38.7 & 26.3 & 14.2 \\
\hline
\end{tabular}

(unit; $\mathrm{g} \mathrm{cal} \cdot \mathrm{cm}^{-2} \cdot \mathrm{day}^{-1}$ ) 


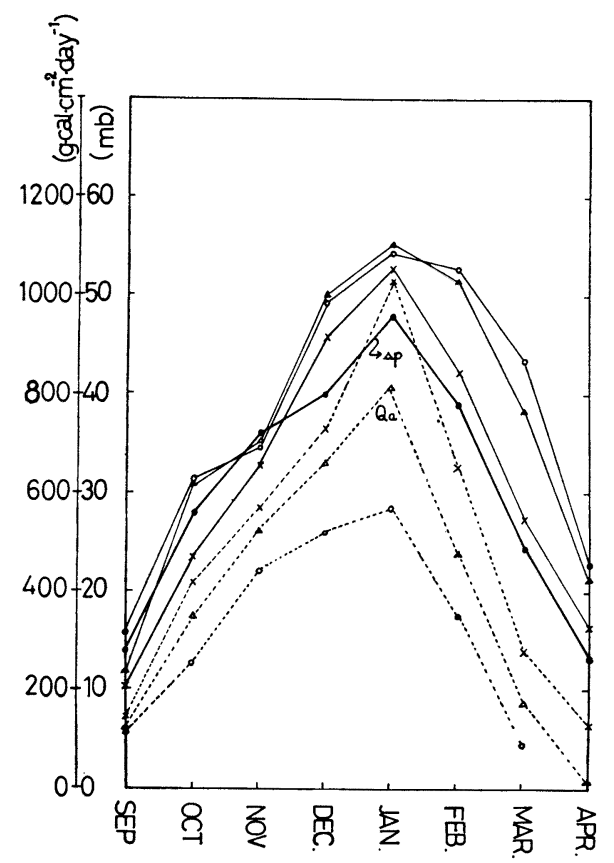

Fig. 5. The mean monthly variation of total energy exchange $\left(Q_{a}\right)$ for the period of $1960-1962$, and the mean monthly variation of the atmospheric "core pressure" difference between the Siberian High and the Aleutian Low $(\Delta p)$.

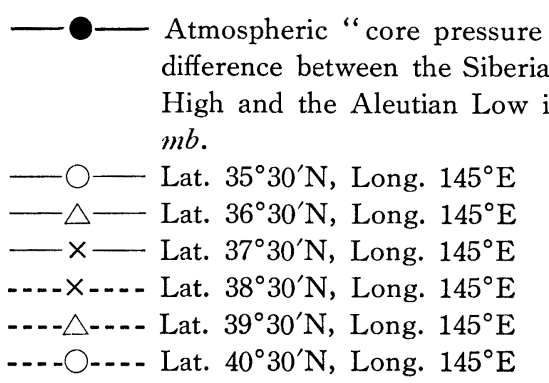

exchange. In January and February, for example, the Bowen ratio in Table 3 which implies the ratio of sensible term to the evaporation term is of about 50 per cent. The above-mentioned is attributed to winter monsoon accompanying the cooling and the lower water vapor content, which prevails over the lower latitude by the relatively warmer Kuroshio current and/or over the higher latitudes of the colder Oyashio current.

Ultimately, the total energy exchange and the atmospheric "core pressure" difference


Fig. 6. Distribution of $Q_{e}$ (solid line) and $Q_{s}$ (dotted line) along the Longitude of $145^{\circ} \mathrm{E}$ from the Lat. $40^{\circ} 30^{\prime} \mathrm{N}$ to Lat. $35^{\circ} 30^{\prime} \mathrm{N}$.

Table 3. The value of $Q_{s k b}$ at the ocean weather stations "EXTRA" and "TANGO" (after M. KoIzUMI, 1956), and the estimated value $\left(E \cdot Q_{s k b}\right)$ in the sea east of Japan.

\begin{tabular}{|c|c|c|c|c|c|c|c|c|}
\hline $\begin{array}{l}\text { Month } \\
\text { Station } \\
\text { and area }\end{array}$ & Sept. & Oct. & Nov. & Dec. & Jan. & Feb. & Mar. & Apr. \\
\hline "EXTRA" & 151 & 92 & 41 & 29 & 50 & 86 & 153 & 208 \\
\hline “TANGO” & 173 & 108 & 85 & 70 & 88 & 120 & 197 & 240 \\
\hline$E \cdot Q_{s k b}$ & 166 & 107 & 56 & 44 & 65 & 101 & 168 & 223 \\
\hline
\end{tabular}

(unit; $\mathrm{g} \mathrm{cal} \cdot \mathrm{cm}^{-2} \cdot \mathrm{day}^{-1}$ )

Station "EXTRA”; Lat. $39^{\circ} \mathrm{N}$, Long. $153^{\circ} \mathrm{E}$

Station "TANGO"; Lat. $29^{\circ} \mathrm{N}$, Long. $135^{\circ} \mathrm{E}$

indicate a remarkable correlation as shown in Fig. 5. Taking the proportional parameter $A$, we get the following equation;

$$
Q_{a}=A \cdot \Delta p
$$

Since $A$ is considered as a function of latitude $\varphi$ and time $t$, it is replaced by

$$
A=f(\varphi) \cdot g(t) .
$$

Since $Q_{a}$ and $\Delta p$ are known values in equation (7), the value $A$ is computed from them. Fig. 7 illustrates the relation between $A$ and latitude 


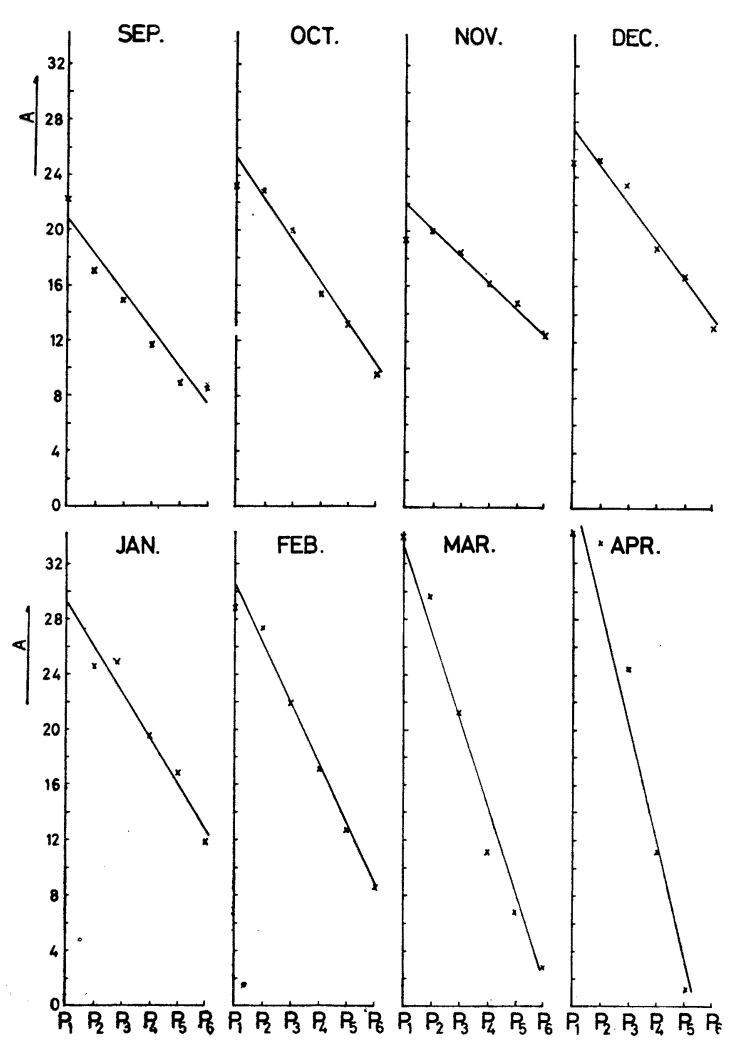

Fig. 7. Relation between $A$ and Latitude $\varphi$ (along the Long. $145^{\circ} \mathrm{E}$ ) in each month from September to April, at the selected six stations in Fig. 3.

$\varphi$, assuming that $g(t)$ is a constant. Since $A$ decreases toward the higher latitude linearly, $f(\varphi)$ be replaced practically in a form of

$$
f(\varphi)=-a \varphi+\alpha .
$$

From the equations (6), (7), and (8), we have

$$
Q_{a}=[(a \varphi+\alpha) \cdot g(t)] \Delta p .
$$

From the above, we can predict quantitatively the mean monthly heat exchange in the sea east of Japan, basing the atmospheric "core pressure" difference from weather map.

\section{Estimation of the net amount of heat by advection}

The net amount of heat $Q_{v}$ which added to or removed from by advective processes is to be computed from the following equation

$$
\begin{aligned}
Q_{v}= & \rho \cdot C_{p}\left[\int_{0}^{\infty} V_{x} \frac{\partial \theta}{\partial x} d z\right. \\
& \left.+\int_{0}^{\infty} V_{y} \frac{\partial \theta}{\partial y} d z+\int_{0}^{\infty} V_{z} \frac{\partial \theta}{\partial z} d z\right],
\end{aligned}
$$

where $V_{x}, V_{y}$, and $V_{z}$ are $x$-, $y$-, and $z$-components of current velocity, respectively. The upper limit of the integral should be, in practice, substituted by the same thermocline depth as in the case of $Q_{\theta}$, while $\rho, C_{p}$, and $\theta$ are the same. Since such combined data of actual observed one are, however, very scanty, we can not compute them at present directly from the above equation.

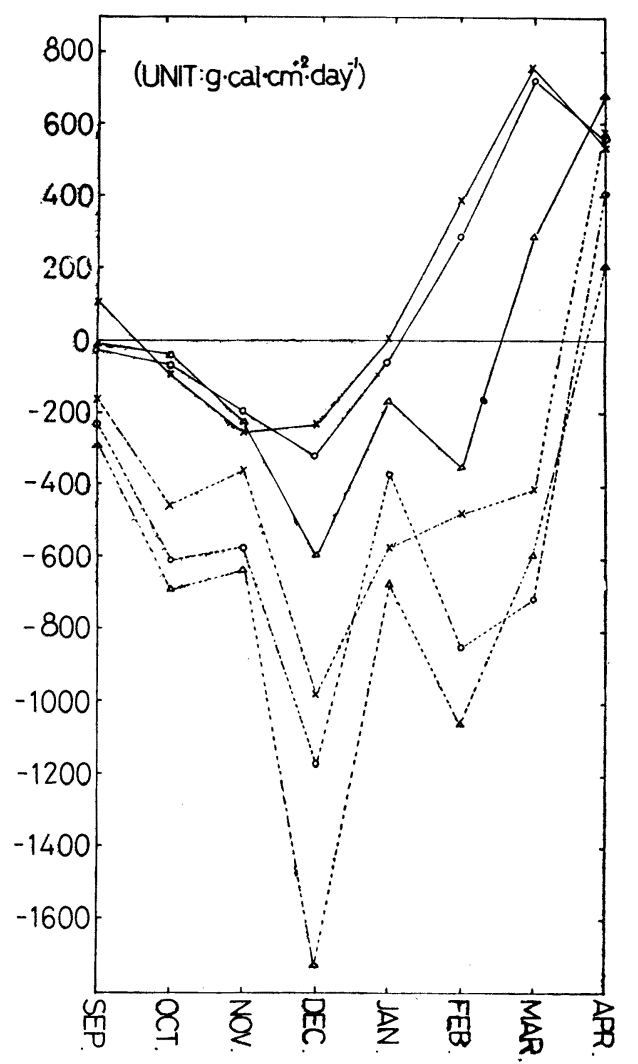

Fig. 8. $Q_{v}$ (amount of heat added to or removed from through advection) in the sea east of Japan from September to April.

$-\times-Q_{v}$ at the Lat. $35^{\circ} 30^{\prime} \mathrm{N}$, Long. $145^{\circ} \mathrm{E}$

$-\bigcirc-Q_{v}$ at the Lat. $36^{\circ} 30^{\prime} \mathrm{N}$, Long. $145^{\circ} \mathrm{E}$

$-\triangle-Q_{v}$ at the Lat. $37^{\circ} 30^{\prime} \mathrm{N}$, Long. $145^{\circ} \mathrm{E}$

.$--\times---Q_{v}$ at the Lat. $38^{\circ} 30^{\prime} \mathrm{N}$, Long. $145^{\circ} \mathrm{E}$

$\ldots-Q_{v}$ at the Lat. $39^{\circ} 30^{\prime} \mathrm{N}$, Long. $145^{\circ} \mathrm{E}$

$\ldots-. . Q_{v}$ at the Lat. $40^{\circ} 30^{\prime} \mathrm{N}$, Long. $145^{\circ} \mathrm{E}$ 
Table 4. The mean monthly amount of sensible heat $\left(Q_{s}\right)$ and the mean monthly amount of heat used for evaporation $\left(Q_{e}\right)$ in $\mathrm{g} \mathrm{cal} \cdot \mathrm{cm}^{-2} \cdot \mathrm{day}^{-1}$, and the Bowen ratio $\left(R=Q_{s} / Q_{e}\right)$.

\begin{tabular}{|c|c|c|c|c|c|c|c|c|c|}
\hline Station & Month & Sept. & Oct. & Nov. & Dec. & Jan. & Feb. & Mar. & Apr. \\
\hline $\begin{array}{l}\qquad P_{1} \\
\text { Lat. } 35^{\circ} 30^{\prime} \mathrm{N} \\
\text { Long. } 145^{\circ} \mathrm{E}\end{array}$ & $\begin{array}{l}Q_{s} \\
Q_{e} \\
Q_{a} \\
R\end{array}$ & $\begin{array}{c}15 \\
293 \\
308 \\
0.05\end{array}$ & $\begin{array}{c}88 \\
539 \\
627 \\
0.16\end{array}$ & $\begin{array}{l}136 \\
553 \\
689 \\
0.25\end{array}$ & $\begin{array}{l}250 \\
741 \\
991 \\
0.34\end{array}$ & $\begin{array}{c}320 \\
774 \\
1094 \\
0.41\end{array}$ & $\begin{array}{c}334 \\
772 \\
1006 \\
0.43\end{array}$ & $\begin{array}{l}232 \\
644 \\
876 \\
0.36\end{array}$ & $\begin{array}{c}15 \\
347 \\
362 \\
0.04\end{array}$ \\
\hline $\begin{array}{l}\quad P_{2} \\
\text { Lat. } 36^{\circ} 30^{\prime} \mathrm{N} \\
\text { Long. } 145^{\circ} \mathrm{E}\end{array}$ & $\begin{array}{l}Q_{s} \\
Q_{e} \\
Q_{a} \\
R\end{array}$ & $\begin{array}{c}30 \\
231 \\
261 \\
0.13\end{array}$ & $\begin{array}{c}88 \\
538 \\
624 \\
0.16\end{array}$ & $\begin{array}{l}148 \\
561 \\
709 \\
0.27\end{array}$ & $\begin{array}{c}269 \\
736 \\
1005 \\
0.37\end{array}$ & $\begin{array}{l}1168 \\
0.46\end{array}$ & $\begin{array}{c}347 \\
716 \\
1063 \\
0.48\end{array}$ & $\begin{array}{l}215 \\
574 \\
789 \\
0.38\end{array}$ & $\begin{array}{c}30 \\
363 \\
393 \\
0.08\end{array}$ \\
\hline $\begin{array}{l}\qquad P_{3} \\
\text { Lat. } 37^{\circ} 30^{\prime} \mathrm{N} \\
\text { Long. } 145^{\circ} \mathrm{E}\end{array}$ & $\begin{array}{l}Q_{s} \\
Q_{e} \\
Q_{a} \\
R\end{array}$ & $\begin{array}{l}-1 \\
206 \\
205 \\
0.00\end{array}$ & $\begin{array}{c}67 \\
479 \\
546 \\
0.14\end{array}$ & $\begin{array}{l}141 \\
512 \\
653 \\
0.28\end{array}$ & $\begin{array}{l}260 \\
677 \\
937 \\
0.38\end{array}$ & $\begin{array}{c}401 \\
781 \\
1182 \\
0.51\end{array}$ & $\begin{array}{l}283 \\
561 \\
844 \\
0.55\end{array}$ & $\begin{array}{l}130 \\
426 \\
554 \\
0.30\end{array}$ & $\begin{array}{l}-2 \\
285 \\
284 \\
0.00\end{array}$ \\
\hline $\begin{array}{l}P_{4} \\
\text { Lat. } 38^{\circ} 30^{\prime} \mathrm{N} \\
\text { Long. } 145^{\circ} \mathrm{E}\end{array}$ & $\begin{array}{l}Q_{s} \\
Q_{e} \\
Q_{a} \\
R\end{array}$ & $\begin{array}{c}-2 \\
162 \\
160 \\
-0.01\end{array}$ & $\begin{array}{c}45 \\
395 \\
440 \\
0.11\end{array}$ & $\begin{array}{l}124 \\
452 \\
576 \\
0.27\end{array}$ & $\begin{array}{l}235 \\
516 \\
751 \\
0.43\end{array}$ & $\begin{array}{l}316 \\
615 \\
931 \\
0.51\end{array}$ & $\begin{array}{l}214 \\
438 \\
652 \\
0.49\end{array}$ & $\begin{array}{c}45 \\
253 \\
298 \\
0.18\end{array}$ & $\begin{array}{c}-2 \\
229 \\
227 \\
-0.01\end{array}$ \\
\hline $\begin{array}{l}\quad P_{5} \\
\text { Lat. } 39^{\circ} 30^{\prime} \mathrm{N} \\
\text { Long. } 145^{\circ} \mathrm{E}\end{array}$ & $\begin{array}{l}Q_{s} \\
Q_{e} \\
Q_{a} \\
R\end{array}$ & $\begin{array}{c}-8 \\
130 \\
122 \\
-0.06\end{array}$ & $\begin{array}{c}35 \\
325 \\
360 \\
0.12\end{array}$ & $\begin{array}{l}128 \\
296 \\
424 \\
0.44\end{array}$ & $\begin{array}{l}204 \\
459 \\
663 \\
0.44\end{array}$ & $\begin{array}{l}286 \\
515 \\
801 \\
0.56\end{array}$ & $\begin{array}{l}158 \\
323 \\
481 \\
0.49\end{array}$ & $\begin{array}{c}16 \\
150 \\
166 \\
0.11\end{array}$ & $\begin{array}{r}-8 \\
68 \\
60 \\
-0.12\end{array}$ \\
\hline $\begin{array}{l}\quad P_{6} \\
\text { Lat. } 40^{\circ} 30^{\prime} \mathrm{N} \\
\text { Long. } 145^{\circ} \mathrm{E}\end{array}$ & $\begin{array}{l}Q_{s} \\
Q_{e} \\
Q_{a} \\
R\end{array}$ & $\begin{array}{c}-11 \\
132 \\
121 \\
-0.08\end{array}$ & $\begin{array}{r}0 \\
258 \\
258 \\
0\end{array}$ & $\begin{array}{l}107 \\
334 \\
441 \\
0.32\end{array}$ & $\begin{array}{l}163 \\
352 \\
515 \\
0.46\end{array}$ & $\begin{array}{l}188 \\
378 \\
566 \\
0.50\end{array}$ & $\begin{array}{l}114 \\
227 \\
341 \\
0.50\end{array}$ & $\begin{array}{r}-14 \\
104 \\
90 \\
-0.14\end{array}$ & $\begin{array}{r}-11 \\
23 \\
12 \\
-0.48\end{array}$ \\
\hline
\end{tabular}

$Q_{a}\left(=Q_{e}+Q_{8}\right) ;$ The mean monthly amount of total energy exchange in $\mathrm{g} \mathrm{cal} \cdot \mathrm{cm}^{-2} \cdot \mathrm{day}^{-1}$.

Therefore, it is reasonable, at present, to use the equation (2). However, in order to estimate roughly the unknown term $Q_{s k b}$, those at the weather stations "EXTRA" and "TANGO" were utilized (after KOIZUMI, 1955). The value $Q_{s k b}$ in the sea east of Japan is estimated roughly as the quantity adding $15 \mathrm{~g} \cdot \mathrm{cal} \cdot \mathrm{cm}^{-2} \cdot$ day $^{-1}$ to the quantity of $Q_{s k b}$ at the weather station "EXTRA".

The values of $Q_{s k b}$ and $Q_{v}$ estimated from the above are indicated in Table 4 and Fig. 8. At the Lat. $35^{\circ} 30^{\prime} \mathrm{N}$ and $36^{\circ} 30^{\prime} \mathrm{N}$, the cooling by advective processes starts in late and early September, respectively, but in early January the warming starts at the both stations. In the northern part bounded by the Lat. $37^{\circ} 30^{\prime} \mathrm{N}$, the cooling by advective processes has appeared in advance of September, the warming also started during the period from mid-February to mid-March. The cooling by advection is, in general, most intensified throughout December in the sea east of Japan, and the corresponding net amount of heat is, for example, approximately 1000,1200 , and $1700 \mathrm{~g} \cdot \mathrm{cal}^{-2} \cdot \mathrm{day}^{-1}$ at the Lat. $38^{\circ} 30^{\prime} \mathrm{N}$, and $39^{\circ} 30^{\prime} \mathrm{N}$ and $40^{\circ} 30^{\prime} \mathrm{N}$, respectively.

It is an interesting fact found in Fig. 8 that in the northern area the curves illustrating 
amount of heat added to or removed from by advection indicate the mimima in October, December, and February and the maxima in November, and January. It might be inferred from the present study of heat budget that the intensity of the Oyashio current fluctuates in short period, and that the north-south shift of the Polar Front or Subarctic Convergence (the Oyashio Front) in the sea east of Japan is affected mainly the Kuroshio current in the warmer season and by the prosperity of the Oyashio current in the colder season.

\section{Concluding remarks}

Finally we are able to stress some procedure or useful prediction indices for the numerical oceanographic forecasting such a way that corresponding to the difference of the core pressure in the colder season year by year.

The monthly amount of total energy exchange at every station can be computed and the resulting rise and fall of sea surface temperature in advance of some months or the intensification of the Oyashio current might be computed numerically by our improved method in future.

Lastly the authors wish to express hearty thanks to Dr. Jotaro MASUZAWA, Japan Meteorological Agency, for his valuable suggestions in preparing this paper.

\section{References}

BJERKNES, J. (1964): Atlantic air-sea interaction. Advanced in Geophysics., Vol. 10, pp. 1-81, Acad. Press. New York and London.

BuDYKo, M. I. (1956): The heat balance of the earth's surface. Hidrometeorologicheskoe izdatel'stvo, Leningrad, pp. 255.

JACOBS, W. C. (1942): On the energy exchange between sea and atmosphere. Jour. Mar. Res., 5, 37-66.

JACOBS, W. C. (1951): Large-scale aspects of energy transformations over the oceans. Compendium of Meteorology, Amer. Met. Soc., 1057-1070.

HANZAWA, M. (1950): On the annual variation of evaporation from the sea surface in the North Pacific Ocean. Oceanogr. Mag., 2, 77-82.
KoIzUMI, M. (1956): Researches on the variations of oceanographic conditions in the region of the ocean weather station "EXTRA" in the North Pacific Ocean (3). Pap. Met. Geophys., 6, 273284.

Laevastu, T. (1963): Energy exchange in the North Pacific-Its relations to weather and its oceanographic consequence-Part 1. Hawaii Inst. Geophys., No. 30.

LAEvASTU, T. (1963): Energy exchange in the North Pacific-Its relations to weather and its oceanographic consequence-Part 2. Hawaii Inst. Geophys., No. 31.

LAEvASTU, T. (1963): Energy exchange in the North Pacific-Its relation to weather and its oceanographic consequence--Part 3. Hawaii Inst. Geophys., No. 32 .

MALKuS, J. S. (1962): Large-scale interaction. The Sea. Vol. 1, 88-294. Interscience Publishers New York-London.

MANABE, S. (1958): On the estimation of energy exchange between the Japan Sea and the atmosphere during winter based upon the energy budget of both the atmosphere and the sea. Jour. Met. Soc. Japan., 36, 123-134.

MASUZAWA, J. (1951): The heat exchange between sea and atmosphere in the southern sea of Japan. Oceanogr. Mag., 7, 67-75.

NAMIAS, J. (1963): Large-scale air-sea interactions over the North Pacific from summer 1962 through the subsequent winter. Jour. Geophys. Res., 68, No. 22.

MIYAZAKI, M. (1952): The heat budget in the Japan Sea. Bull. Hokkido Regional Fish. Res. Lab., No. 4, 1-54.

OTsUKA, K. (1965): On the unusual low temperature in the East China Sea in winter of 1963 discussed from the heat balance. Ocean. \& Met., 15, 326-333.

PetTERSSEN, S. (1962): Weather analyses and Forecasting. Vol. 1. Mcgraw-Hill Book Company, Inc.

SVERDRUP, H. U. (1937): On the evaporation from the oceans. Jour. Mar. Res., 1, 3-13.

SVERDRUP, H. U. (1947): On the annual and diurnal variation of the evaporation from the oceans. Jour. Mar. Res., 3, 93-104.

WYRTKI, K. (1965): The average annual heat balance of the North Pacific Ocean and its relation to ocean circulation. Jour. Geophys. Res., 70 (18). 


\title{
本州東方沖合の海と大気のエネルギー交換について
}

\author{
本橋敬之助宇田道隆
}

\begin{abstract}
要旨 本州東方沖合飞適当な 6 点を選び, 1960 1962 年 と時間 $(t)$ 飞依存し, 実用的には $f(\varphi)$ は $(-a \varphi+\alpha)$ で の 3 か年にわたって大気と海洋の間の熱収支について研 惪き換元得る。この式で本州東方沖合上の総エネルギー 究した. その 3 か年にわたる総エネルギー交換量と海表 交換量が気圧分布に基づいて定量的に予測できる。熱収 面水温の月変化の関係は総エネルギー交換量の減（增） 支の観点から寒候期の親潮飞よる冷却は 12 月飞最も著 約 2 か月後海表面水温の增（減）を示した. 総エネルギ しく, かつ本州東方海域は緯度 $37^{\circ} 30^{\prime}$ 付近を境界とし 一交換量 $\left(Q_{a}\right)$ とシベリア高気圧とアリューシャン低気 圧の中心気圧差 $(\Delta p)$ には $Q_{a}=[f(\varphi) \cdot g(t)] \cdot \Delta p$ で表 わせる密接な相関があった．ここで比例係数は緯度 $(\varphi)$ て次の二つの海域,すなわち黒潮の影響を強く受ける南 部海域と親潮の影響を強く受ける北部海域に分けて得ら れる。
\end{abstract}

